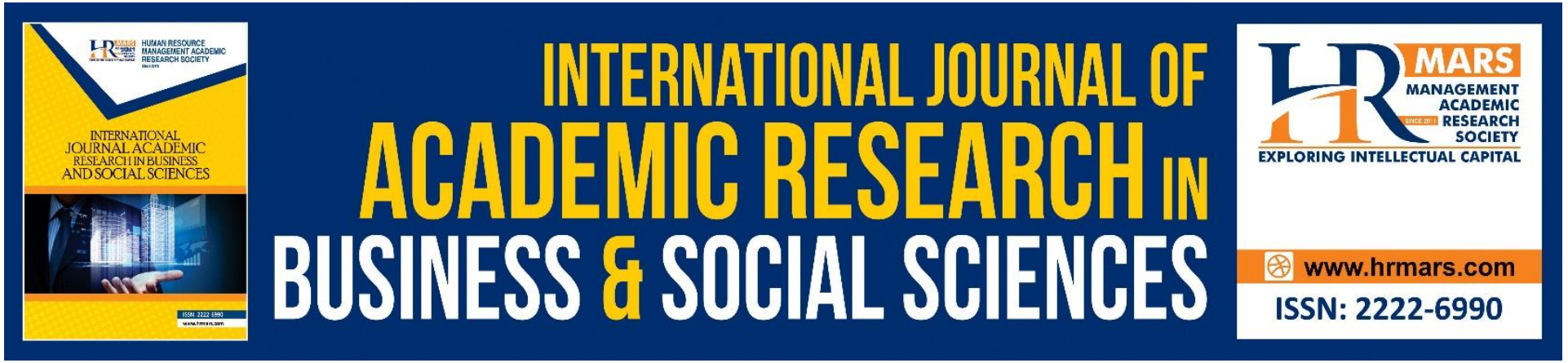

\title{
An Exploratory Factor Analysis of the Awareness of Fundamental Liberties among Students
}

\author{
Hazlina Mohd Padil, Nor Laila Ahmad, Noorsaliza Amin Nudin
}

To Link this Article: http://dx.doi.org/10.6007/IJARBSS/v11-i9/10882

DOI:10.6007/IJARBSS/v11-i9/10882

Received: 08 July 2021, Revised: 28 July 2021, Accepted: 20 August 2021

Published Online: 19 September 2021

In-Text Citation: (Padil et al., 2021)

To Cite this Article: Padil, H. M., Ahmad, N. L., \& Nudin, N. A. (2021). An Exploratory Factor Analysis of the Awareness of Fundamental Liberties among Students. International Journal of Academic Research in Business and Social Sciences, 11(9), 1129-1143.

Copyright: @ 2021 The Author(s)

Published by Human Resource Management Academic Research Society (www.hrmars.com)

This article is published under the Creative Commons Attribution (CC BY 4.0) license. Anyone may reproduce, distribute, translate and create derivative works of this article (for both commercial and non-commercial purposes), subject to full attribution to the original publication and authors. The full terms of this license may be seen at: http://creativecommons.org/licences/by/4.0/legalcode

Vol. 11, No. 9, 2021, Pg. 1129 - 1143

Full Terms \& Conditions of access and use can be found at http://hrmars.com/index.php/pages/detail/publication-ethics 


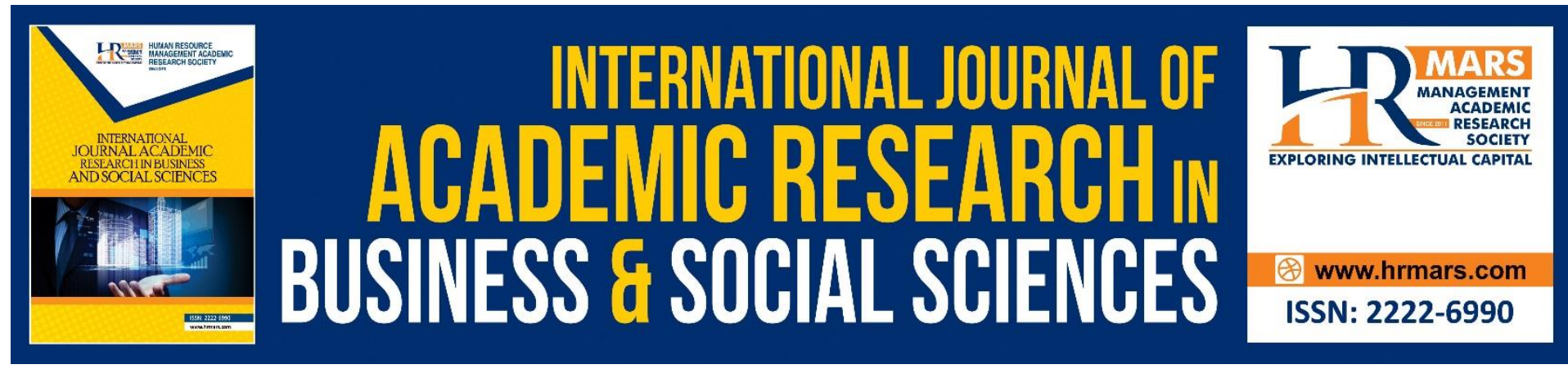

\title{
An Exploratory Factor Analysis of the Awareness of Fundamental Liberties among Students
}

\author{
Hazlina Mohd Padil ${ }^{1}$, Nor Laila Ahmad ${ }^{1 *}$, Noorsaliza Amin \\ Nudin ${ }^{2}$
}

${ }^{1}$ Faculty of Law, Universiti Teknologi MARA Cawangan Negeri Sembilan, Kampus Seremban, Negeri Sembilan Malaysia, ${ }^{2}$ Faculty of Law, Universiti Teknologi MARA Cawangan Pulau

Pinang, Kampus Permatang Pauh, Pulau Pinang, Malaysia

Corresponding Author: norlailaahmad@uitm.edu.my

\begin{abstract}
Malaysian citizens should be aware of their basic rights under the Federal Constitution known as 'fundamental liberties'. However, not many citizens are aware of their basic rights and research on the awareness of citizen's basic rights is sparse. Thus, this study intended to develop a measurement instrument which can later be used to analyse the factors that constitutes the awareness of fundamental liberties among students. An exploratory factor analysis was conducted to find the factors that will be the measurement instrument in identifying the awareness of fundamental liberties among students. This research employed a quantitative research design where an online questionnaire responded by 455 university students was analysed using the Statistical Package for Social Science (SPSS) version 24. A total of 3 factors consist of 17 items were extracted from the exploratory factor analysis. The results will be the measurement instrument for further analysis on the awareness of fundamental liberties among students.
\end{abstract}

Keywords: Exploratory Factor Analysis, Citizen, Awareness, Fundamental Liberties, Students

\section{Introduction}

Federal Constitution is the supreme law of Malaysia as provided in Article 4(1) of the Federal Constitution where any law passed after the Merdeka Day which is contrary to the Federal Constitution shall be void and may be challenged in court. The Federal Constitution is the Malaysia's legal foundation that plays a significant role in determining the identity of Malaysia. It is the most vital document that serves as a social contract between the states and its citizens (Hassan et al., 2018; Fairojibanu, 2018; Khasasi, 2020). Among the important provisions in the Federal Constitution are the fundamental liberties which contain the basic rights of the citizens of Malaysia. The fundamental liberties govern the right to life and personal liberty (Article 5), prohibition on slavery and labour force (Article 6), protection against retrospective criminal laws and repeated trials (Article 7), equal protection of the law (Article 8), right to move freely and reside throughout the federation (Article 9), right to freedom of speech and expression (Article 10), right to profess and practise religion (Article 11 ), rights in respect of education (Article 12) and rights to property (Article 13). However, 
these fundamental liberties are not absolute and subject to certain well-defined restrictions such as security of the federation, public order, morality, and defamation (Nudin et al., 2020).

All citizens should be aware of the basic rights in the Federal Constitution. Lack of awareness and understanding of the basic rights led to problems such as infringement of the Federal Constitution and misunderstanding of the law (Chin, 2017; Anuar, 2018). Controversial cases on infringement of fundamental liberties such as the case of Adam Adli, Alvin Tan, and Namewee became a polemic as to whether the youths are attentive of their rights as citizens or just a 'puppet' to be manipulated by interested parties (Hasan et al., 2018). Hence, it is important that the Malaysians understand and aware of the rights granted in the Federal Constitution.

Fundamental liberties are the main pillar of the Constitution, it needs to be understood by every layer of the society, including the younger generations. Research on awareness of a citizen's basic rights is sparse, thus this study intended to identify the factors that constitutes awareness of fundamental liberties among students. Since this study did not based on any theory, an exploratory factor analysis was employed to establish a validated and reliable measurement instrument before further analysis can be done to examine the factors that contribute to the awareness of fundamental liberties among students.

\section{Literature Review}

\section{Federal Constitution and Fundamental Liberties}

Fernando and Rajagopal (2017) found numerous legal studies that have been conducted on fundamental liberties in Malaysia which emphasised on the understanding the basic rights of every citizen. They opined that the fundamental liberties are a special set of laws which are designed to protect the citizens' fundamental civil, political, and economic freedoms. Adil and Ahmad (2014) stated that fundamental liberties reflect the basic human rights guaranteed by the citizens. According to Aun (2003), the fundamental liberties in the Constitution act as a safeguard against the abuse of power, namely from the executive authority of the country. Even though the fundamental liberties envisaged the right to legal representation under Article 5 of the Federal Constitution, the author viewed that the biggest power and authority also conferred on the police to arrest any person based on the various legislations. The further stressed that a greater transparency in society would be achieved by observing the fundamental liberties in the Constitution. According to Thurairaj et al (2018), the awareness campaigns on the importance of patriotism held by the government through education focusing on young generation has transformed the attitude of Malaysians. These campaigns have created constitutional patriotism, which they take cognizant of their rights to defend their fundamental liberties when they feel they have been treated unfairly.

Every citizen not only needs to be aware of the constitutional rights available in Article 5 to Article 13 of the Federal Constitution, but they also must be aware of the available remedies for infringement of constitutional rights provided by the law in Malaysia such as prerogative orders, declaration, monetary compensation and consequential orders. Paragraph 1 of the Schedule on Additional Powers of the High Courts in the Courts of Judicature Act 1964 provided the remedies which states, "Power to issue to any person or authority directions, orders or writs, including writs of the nature of habeas corpus, mandamus, prohibition, quo 
warranto and certiorari, or any others, for the enforcement of the rights conferred by Part II of the Constitution, or any of them, or for any purpose".

Kai-Ming (2020) referred to the case of Hasan bin Marsom \& Ors v Mohd Hady bin Ya'akop [2018]5 MLJ 141 where the Federal Court ruled that in every case where a man is wronged, he must have a remedy especially when his constitutional rights have been infringed. The author also referred to the case of Ketua Polis Negara \& Ors v Nurasmira Maulat bt Jaafar \& Ors [2018]3 MLJ 184 where the Federal Court's judge, Zainun Ali opined that a breach of a constitutional rights should result in an appropriate constitutional remedy. This showed that the courts are willing and empowered to remedy cases on infringement of constitutional rights for justice. Whenever needed, legal aid will assist vulnerable individuals, including the non-citizens (Wahab \& Khairi, 2020). Without access to legal aid such as private law firms, law faculties and non-governmental organizations, millions of vulnerable people across the globe are at risk of their rights being ignored and violated. Ekmekci and Arda (2015) argued that in many democratic countries, the fundamental rights are already being guaranteed by the constitution but the failure to provide fair access to legal aid will lead to other deprivations of liberties and social inequalities.

\section{Awareness}

The word "aware" is used in many contexts with many different connotations. According to Gafoor (2012), awareness means knowledgeable being conscious with an ability to perceive and to feel objects, events or sensory patterns. The author further emphasized the three meanings of awareness. Firstly, awareness in the context of education which can be regarded as knowledge without any direct teaching. Next, awareness can be defined as self-perceptions from the perspective of psychology where self-awareness such as emotional, body or strength awareness are indicated as unique perceptions are considered as a higher form of awareness. The third meaning of awareness that is classified by the author concerns an ability to deal with the specific task and situation which can be assessed using the Computer Awareness Test and Awareness Skills.

Malaysians should be aware of the fundamental liberties since these fundamental liberties may be violated and manipulated by irresponsible parties who have interest and monopoly over society, failure which may lead to conflict of social inequality (Tehupeiory \& Naibaho, 2020). A study conducted by Agarwal (2014) on the knowledge of human rights among people in Agra City, India, showed that people do not have much knowledge and awareness about the basic concept of individual rights. The author further remarked that human rights education is compulsory for the promotion and achievement of harmonious relations among the society. Thus, legal awareness of fundamental rights should be integrated among the young generation across the entire school and university activities. Singh and Singh (2015) viewed that educators play a significant role in the whole teaching and learning in the context of generating fundamental rights awareness among students. Based on a survey conducted among hundred students at four B.Ed. colleges from a district of Punjab state, India, the authors found that most of the students were aware of their fundamental rights. However, the result showed less awareness of the protection of these rights. Hamid and Mohammad (2018) suggested that educators should be aware of and comprehend their professions on legal requirements. Therefore, they must also be familiar with the law and before they can deliver the knowledge and awareness of fundamental liberties to others this is because the 
knowledge on fundamental human rights in universities is imparted via lectures, tutorials, assignments, problem-based learning and assessed in examinations (Nordin \& Abdullah, 2017).

Teruel et al (2018) stated that multiple studies have been carried out about awareness, providing a constellation of awareness interpretations. According to them, the most widely accepted interpretations are Collaboration Awareness, Situational Awareness, Workspace Awareness, Location Awareness, Context Awareness, Social Awareness, Activity Awareness, Knowledge Awareness and Shared-Knowledge Awareness. Another researcher, Gafoor (2012) emphasized that awareness can be measured with three different nomenclatures, scales, tests or questionnaires which depends on the purpose of the measurement and awareness as self-reports can be explored in the form of opinion or direct questions.

Wahab and Khairi (2020) referred to John Rawls's theory of justice which emphasised that social institutions distribute the social goods should be structured to act in accordance with the principles of justice while distributing the fundamental rights and responsibilities. They further found that Rawls's theory on equal liberty means that each individual should have equal fundamental rights including political liberties, liberty of conscience, freedom of speech, freedom of expression, self-respect, right to property and freedom of thought. Thus, awareness of fundamental rights can be achieved when each individual has access to the services he/she needs (Ekmekci \& Arda, 2015). Access to information and dissemination of information in the age of digital information technology is best done by using the internet (Omeje, Osuagwu and Ugwu, 2021). Use of digital technology has enabled an easier access for the students and citizens to know on fundamental liberties contrary to the conventional method of dissemination of information (Nudin et al., 2020). Attending seminars/courses relating to Federal Constitution helped participants to understand and aware of the fundamentals of the law (Hasan et al., 2018).

\section{Research Methodology}

This study employs a quantitative research design where EFA was adopted to develop the factors (Williams et al., 2010, as cited in Padil et al., 2020) that can determine the awareness of fundamental liberties among the students of Universiti Teknologi MARA (UiTM), Malaysia. EFA is the first step in building scales or new metrics, used when a researcher wants to discover the number of factors influencing variables and to analysis which variables 'go together' (DeCoster, 1998 as cited in Yong \& Pearce, 2013). EFA is a statistical is a technique meant to reduce the large number of items to a smaller number of factors which will be the variables for the study (Spinde et al., 2021).

Data was collected through an online questionnaire from the students of UiTM and 455 students responded to the survey. Collected data was then analysed using the Statistical Package for Social Science (SPSS) version 24. The questionnaire was divided into two parts where Part A was designed for the demographic analysis of the respondents. Part B of the same survey consists of 24 items measured using a five-point Likert scale with response format such as $1=$ =strongly disagree, $2=$ disagree, $3=$ neither agree nor disagree, 4=agree and $5=$ strongly agree. Since the study was not based on any prior theory, exploratory factor analysis was employed to identify the number of factors relevant to the study. Other methods of analysis such as Parallel Analysis and Minimum Average Partial Criteria (MAP) were also 
conducted to confirm the number of factors derived from the analysis. The factors extracted from the analysis will constitute the variables for further study.

\section{Result and Discussion}

Before EFA can be carried out, the sample size must be determined first to avoid distortion on the results of analysis. The rule of thumb suggested that the subject to item ratio is 10:1 (Hair et al., 2006). In this study there are 24 items, hence a total of 240 samples should be collected. Since this study has collected 455 samples, it can be said that the samples were sufficient to run EFA. Data was screened for extreme scores and normality distribution of data. Mahalanobis distance was used to deal with the extreme scores or the outliers which will affect the results of the analysis. Results from the Mahalanobis distance analysis which have extreme values can be removed from the dataset for being the outliers (Hair et al., 1998, as cited in Walsh, 2012). The values were interpreted using the chi-square distribution in order to remove the outliers. Data was transformed and analysed based on the probability values of Mahalanobis distance. Any cases which are less than $p$-value of 0.001 are multivariate outliers. From the results of $p$-values, there were 24 cases which were less than 0.001 and have been removed.

Normality test was then conducted to test whether the data was normally distributed. It is important to test the normality of data to decide on the extraction method in the exploratory factor analysis. Shapiro-Wilk Tests are powerful to determine the normality of the distribution (Ogunleye, 2018). From the Shapiro-Wilk Tests, values greater than 0.05 indicated that the data is normally distributed whilst data less than 0.05 indicated that the data is deviated from normal distribution (Sormin et al., 2019). The values from the Shapiro Wilk Tests in this study were significant where $p<0.05$, confirmed that the data were not normally distributed.

From the aforesaid preliminary analysis on identifying extreme scores, 24 cases were removed for being the outliers, the data was then analysed for only 431 cases. Based on the descriptive analysis, the respondents were made up of $29.9 \%$ male and $70.1 \%$ female. A total of $87.5 \%$ and $12.5 \%$ of the respondents were from the diploma program and degree program, respectively. Only one student, who made up $0.2 \%$ of the respondents was below 18 years old while three students or $0.7 \%$ were above 25 years old. A total of $89.1 \%$ of the respondents were in the category of 18-21 years old and the students in the range of age from 22-25 years old only made up $10 \%$ of the respondents. The overall demographic results on the profiles of the respondents such as gender, age and program are shown in Table 1 below. 
Table 1: Demographic of Respondents

\begin{tabular}{|c|c|c|}
\hline Profile & $\begin{array}{l}\text { Frequency } \\
\text { (n) }\end{array}$ & $\begin{array}{l}\text { Percentage } \\
\text { (\%) }\end{array}$ \\
\hline \multicolumn{3}{|l|}{ Gender } \\
\hline Male & 129 & 29.9 \\
\hline Female & 302 & 70.1 \\
\hline \multicolumn{3}{|l|}{ Age } \\
\hline Below 18 years old & 1 & 0.2 \\
\hline 18-21 years old & 384 & 89.1 \\
\hline 22-25 years old & 43 & 10 \\
\hline Above 25 years old & 3 & 0.7 \\
\hline \multicolumn{3}{|l|}{ Program } \\
\hline Diploma & 377 & 87.5 \\
\hline Degree & 54 & 12.5 \\
\hline
\end{tabular}

Source: SPSS Analysis

The data was further analysed using EFA to determine whether the items are within the same construct. Principle axis factoring (PAF) method was used for the extraction in the factor analysis due to the non-normality of the data (Costello \& Osborne, 2005). The correlation matrix is the value of the strength of the relationships between the items. Tabachnick and Fidell (2001) suggested that any correlation less than 0.30 is not correlated with any factor and should be removed. From the result, there are three items (i.e., items B2, B3 and B4) to be removed since the correlation values were less than 0.30 . From the same analysis, the result of the Kaiser-Keyer-Olkin test of sampling adequacy as shown in Table 2 proved that the sample is adequate since the result is 0.940 which exceeded the minimum value of 0.5 (Kaiser, 1981). The Bartlett Test of Sphericity also showed that the result is significant $(p<0.05)$, and it also suggested that exploratory factor analysis is appropriate and will yield useful information for the study.

Table 2: KMO and Bartlett's Test

\begin{tabular}{lll}
\hline Kaiser-Meyer-Olkin Measure of Sampling Adequacy & .940 \\
Bartlett Test of Sphericity & Approx. Chi-Square & 6848.756 \\
& df & 276 \\
& Sig. & .000 \\
\hline
\end{tabular}

Source: SPSS Analysis

The analysis will also examine for communalities which are the extent when the items correlate with other items, or the variance contributed to the factors in the factor solution. Any value of 0.8 in the communalities is considered high, values between 0.40 and 0.70 is considered low to moderate and any value of communalities which are lower than 0.40 shows that the item is not related to the other item (Costello \& Osborne, 2005). From Table 3 below, about four items (i.e., items B1, B3, B4 and B5) were lower than 0.40 and can be removed when exploring the potential factor. 


\section{Table 3: Communalities}

\begin{tabular}{lll} 
& Initial & Extraction \\
\hline A1 & .720 & .685 \\
A2 & .708 & .643 \\
A3 & .667 & .616 \\
A4 & .730 & .720 \\
A5 & .509 & .434 \\
A6 & .682 & .662 \\
A7 & .643 & .640 \\
A8 & .760 & .745 \\
A9 & .681 & .623 \\
B1 & .329 & .318 \\
B2 & .400 & .540 \\
B3 & .307 & .384 \\
B4 & .380 & .483 \\
B5 & .335 & .274 \\
B6 & .579 & .544 \\
B7 & .668 & .763 \\
B8 & .549 & .566 \\
B9 & .669 & .593 \\
B10 & .673 & .637 \\
B11 & .717 & .692 \\
B12 & .661 & .629 \\
B13 & .597 & .661 \\
B14 & .497 & .488 \\
B15 & .550 & .597 \\
\hline Extraction Method: Principal Axis Factoring. \\
& Source: SPSS Analysis
\end{tabular}

In order to determine the number of factors to be retained, one of the methods is by using the Kaiser Criterion where eigenvalue greater than one are retained for interpretation (Kaiser, 1960, as cited in Haslbeck \& Bork, 2021). The extraction for the exploratory factor analysis is using the Principal Axis Factoring since the data was not normally distributed. The number of factors extracted can be seen from Table 4 on the Total Variance Explained where the eigenvalues greater than one were explained at four stages which means if following the Kaiser Criterion, a total of four factors will be retained for further analysis. 
Table 4: Total Variance Explained

\begin{tabular}{|c|c|c|c|c|c|c|}
\hline \multirow[b]{2}{*}{ Factor } & \multicolumn{3}{|c|}{ Initial Eigenvalues } & \multicolumn{3}{|c|}{ Extraction Sums of Squared Loadings } \\
\hline & Total & $\%$ of Variance & Cumulative \% & Total & $\%$ of Variance & Cumulative \% \\
\hline 1 & 10.926 & 45.524 & 45.524 & 10.542 & 43.927 & 43.927 \\
\hline 2 & 2.102 & 8.759 & 54.284 & 1.658 & 6.909 & 50.836 \\
\hline 3 & 1.456 & 6.065 & 60.349 & 1.025 & 4.269 & 55.106 \\
\hline 4 & 1.122 & 4.676 & 65.025 & .713 & 2.970 & 58.076 \\
\hline 5 & .857 & 3.572 & 68.597 & & & \\
\hline 6 & .736 & 3.067 & 71.664 & & & \\
\hline 7 & .721 & 3.003 & 74.667 & & & \\
\hline 8 & .688 & 2.867 & 77.534 & & & \\
\hline 9 & .604 & 2.516 & 80.050 & & & \\
\hline 10 & .545 & 2.273 & 82.323 & & & \\
\hline 11 & .508 & 2.118 & 84.441 & & & \\
\hline 12 & .475 & 1.977 & 86.418 & & & \\
\hline 13 & .415 & 1.729 & 88.147 & & & \\
\hline 14 & .380 & 1.582 & 89.729 & & & \\
\hline 15 & .353 & 1.472 & 91.200 & & & \\
\hline 16 & .322 & 1.340 & 92.540 & & & \\
\hline 17 & .296 & 1.235 & 93.775 & & & \\
\hline 18 & .284 & 1.184 & 94.960 & & & \\
\hline 19 & .262 & 1.091 & 96.051 & & & \\
\hline 20 & .224 & .931 & 96.982 & & & \\
\hline 21 & .208 & .868 & 97.850 & & & \\
\hline 22 & .185 & .772 & 98.622 & & & \\
\hline 23 & .174 & .724 & 99.346 & & & \\
\hline 24 & .157 & .654 & 100.000 & & & \\
\hline
\end{tabular}

Extraction Method: Principal Axis Factoring.

Source: SPSS Analysis

The next method used to determine the number of factors to be retained was by examining the scree plot in Figure 1. The point where the curve starts to level at the eigenvalue $=1$ is in between the factor number 4 and factor number 5 . Based on the point of intersection it can be concluded that there are four factors that can be derived from the analysis. 


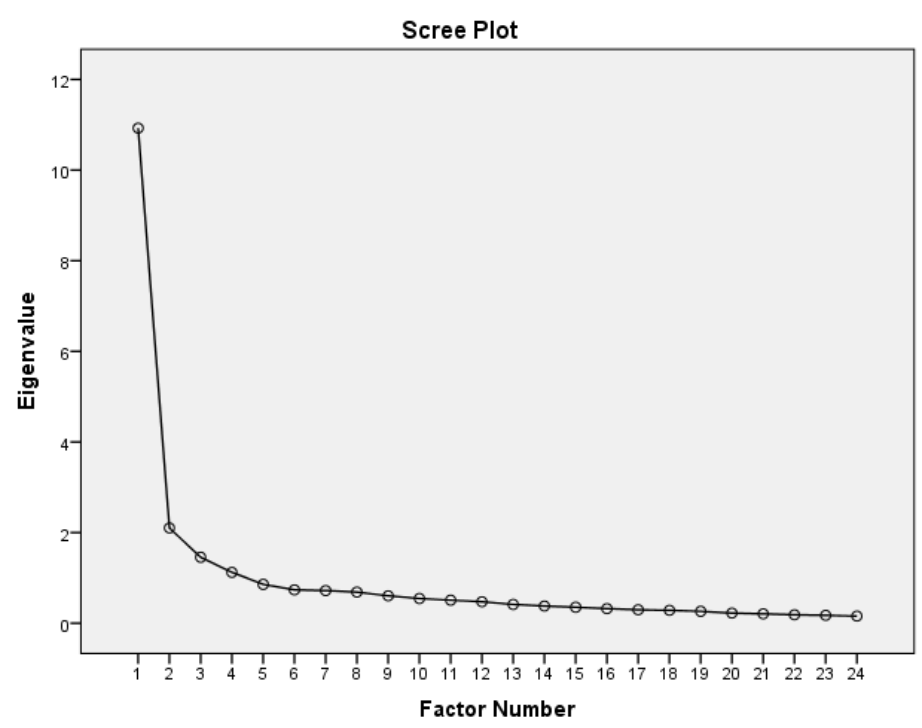

Source: SPSS Analysis

Figure 1: Scree Plot

However, the result in Figure 1 cannot be taken as final that only four factors can be extracted. A further analysis using the SPSS Syntax for Parallel Analysis (O'connor, 2000) was performed to obtain an accurate number of factors. In the Parallel Analysis, the eigenvalues from exploratory factor analysis will be compared with the eigenvalues of generated random data. The factor will be retained if the eigenvalue in exploratory factor analysis is higher than the eigenvalue of random data generated in the Parallel Analysis. The decision of the analysis is in Table 5, and it can be concluded that only three factors can be extracted from the exploratory analysis.

Table 5: Parallel Analysis

\begin{tabular}{|c|c|c|c|}
\hline $\begin{array}{l}\text { Eigenvalues } \\
\text { Exploratory } \\
\text { Analysis }\end{array}$ & $\begin{array}{l}\text { from } \\
\text { Factor }\end{array}$ & $\begin{array}{l}\text { Eigenvalues } \\
\text { of random } \\
\text { data }\end{array}$ & Decision \\
\hline 10.926 & & 1.449427 & Retain \\
\hline 2.102 & & 1.379544 & Retain \\
\hline 1.456 & & 1.323682 & Retain \\
\hline 1.122 & & 1.277635 & Reject \\
\hline 0.857 & & 1.233294 & Reject \\
\hline
\end{tabular}

Source: Own Analysis Based on SPSS result and Parallel Analysis

The study was further analysed using the Minimum Average Partial Criteria (MAP) to determine the number of factors to be extracted (O'connor, 2000). The MAP test was run in SPSS using the syntax MAP and it produced the result "The Number of Components According to the Revised (2000) MAP Test is 3". This confirms that the number of factors to be extracted is 3 .

Next, a rotation was performed in the exploratory factor analysis to obtain a structure of loadings to interpret the factors. This study assumes that the factors were correlated and hence an oblique rotation using promax was performed. The Pattern matrix produced in the 
output was used to examine the factor loadings and the Structure matrix is the report on the correlation between the items and the latent variables. The Pattern matrix was examined for item loadings and any item less than 0.3 has been excluded based on the suppression during the analysis. Items with cross loadings were identified and items which more than 0.32 on at least 2 factors were deleted. At this juncture, items B9, B10 and B11 will be deleted due to cross loading and item B2 will be deleted for no loading. Then the number of items within each construct was examined and Hair et al. (2010) suggested that each construct should contain at least 3 items to be better explained. Any loading below than 0.4 was also dropped from the factors since Guadagnoli and Velicer (1988) considered scores greater than 0.4 to be acceptable.

All the three factors were then tested for validity and reliability. If the measures showed high validity, it means that the concept studies are accurately represented by the items of the instrument. This study further examined the discriminant validity on the extent to which the factors are distinct and uncorrelated. The discriminant validity measures that the constructs theoretically should not be highly related to each other. The factor correlation matrix in Table 6 should not exceed 0.7 (Gaskin, 2021) since any correlation that is greater than 0.7 indicates a majority of shared variance. The result in Table 6 shows that discriminant validity is achieved, and no issue of multicollinearity is present.

Table 6: Factor Correlation Matrix

\begin{tabular}{llll} 
Factor & 1 & 2 & 3 \\
\hline 1 & 1.000 & .501 & .604 \\
2 & .501 & 1.000 & .576 \\
3 & .604 & .576 & 1.000 \\
\hline
\end{tabular}

Extraction Method: Principal Axis Factoring.

Rotation Method: Oblimin with Kaiser Normalization.

Source: SPSS Analysis

The extracted factors were then tested using the Cronbach's alpha coefficient of internal consistency to investigate how well the items that make up the instrument in this study fit together. George and Mallery (2003) provide that Cronbach's alpha $\geq 0.9$ is considered excellent, $\geq 0.8$ is good and $\geq 0.7$ is acceptable. Based on the reliability test in Table 7 , the results showed Cronbach's alpha values above 0.8 which further mean that the instrument is reliable.

Table 7: Reliability Test Result

\begin{tabular}{lll}
\hline Factors & $\begin{array}{l}\text { Cronbach's } \\
\text { Alpha }\end{array}$ & $\begin{array}{l}\text { No. of } \\
\text { Items }\end{array}$ \\
\hline Factor 1 & 0.940 & 10 \\
Factor 2 & 0.831 & 3 \\
Factor 3 & 0.810 & 3 \\
\hline
\end{tabular}

Source: SPSS Analysis

Based on the factor analysis and confirmation on the reliability of those items in the factors, a total of seven items were dropped from the factors. This produced a result of 17 items which can be classified in three distinctive extracted factors as shown in Table 8. 
Table 8: Extracted Factors

\begin{tabular}{ll}
\hline Factor & Item \\
\hline Factor 1 & I am aware of the protection of right to life and liberty. \\
I am aware of the prohibition on slavery and forced labour. \\
I am aware of the protection against retrospective criminal laws and repeated \\
trials. \\
I am aware of the equality before the law and equal protection of the law. \\
I am aware that no citizen shall be punished from the federation \& that every \\
citizen has the right to move freely throughout the federation \& to reside in \\
any part thereof. \\
I am aware that every citizen has the right to freedom of speech and expression, \\
to assemble peacefully and without arms \& to form association. \\
I am aware that every person has a right to profess and practice his religion and \\
subject to Article 11 (4), to propagate it. \\
I am aware of the protection of the rights in respect of education whereby there \\
shall be no discrimination as to religion, race, descent or place of birth. \\
I am aware that every citizen has the right to own property. \\
I obtain information on Fundamental Liberties from friends. \\
I know that the restrictions on 'Fundamental Liberties' are reasonable. \\
I have heard the words 'Fundamental Liberties'. \\
I am familiar with the meaning of 'Fundamental Liberties'. \\
I have learned about 'Fundamental Liberties'.
\end{tabular}

Source: SPSS Analysis

The three extracted factors are the variables in the study which will be categorised according to its group. The variables are attributable to a distinct factor and that factor will be renamed. Factor 1 will be renamed as "Awareness" while Factor 2 and Factor 3 will be renamed as "Familiarity" and "Restrictions" respectively. The new variables will be used for further analysis in future research.

Fundamental liberties are important in the citizen's daily lives. Factor 1 gathered items relevant to the awareness of fundamental liberties and this will be the dependent variable in the next research. Both Factor 2 and Factor 3 are the independent variables which can be further tested for their relationship with the dependent variable.

\section{Conclusion \& Recommendations}

The study analysed the factors which will be used in determining the awareness of fundamental liberties among students. Analysis of the EFA resulted to a reduction of 24 items to 17 items in 3 factors. The factors can be renamed as "Awareness", "Familiarity" and "Restrictions". This study discovers the relationship between knowledge and restrictions with the awareness of the fundamental liberties. The relationship of the factors indicated that from the students' point of view, they will only be aware if they are familiar and know the restrictions when the dimensions of rights under the fundamental liberties involve a lot of 
elements such as rights relating to social life, human values, citizenship and other civil rights. The study contributes to the literature on EFA and a better understanding as how to advocate citizens in knowing and aware of their rights. The results of the EFA produced a validated and reliable measurement instrument for further research and help to develop a measurement instrument to assess the awareness of fundamental liberties among Malaysian citizens. It is recommended to increase the number of items and respondents to obtain more factors for a better measurement instrument in future research.

\section{References}

Adil, M. A. M., \& Ahmad, N. M. (2014). Islamic law and human rights in Malaysia. ICR Journal, 5(1), 43-67.

Agarwal, A. (2014). Human rights awareness among the people of Agra City: A comparative study. Journal of Culture, Society and Development, 3, 36-42.

Aun, K. K. S. (2003). The role of fundamental liberties in the evolution of Malaysia as a democratic society. The Journal of the Malaysian Bar, XXXII(No 2), 50-64.

Chin, L. C. (2017). A Malaysia of citizens: Ethnicity, membership and politics of merger. KEMANUSIAAN: The Asian Journal of Humanities, 24(2). 1-30.

Costello, A. B., \& Osborne, J. W. (2005). Best practices in exploratory factor analysis: Four recommendations for getting the most from your analysis. Practical Assessment, Research \& Evaluation, 10(1),7.

Ekmekci, P. E., \& Arda, B. (2015). Enhancing John Rawls's theory of justice to cover health and social determinants of health. Acta Bioethica, 21(2), 227-236.

Fairojibanu, N. M., \& Samian, A. L. (2018). The pilot study on the perception of the society towards the Federal Constitution from the aspect of racial unity. International Journal of Academic Research in Business and Social Science, 8(11), 274-284. DOI 10.6007/IJARBSS/v8-i11/4899

Fernando, J. M., \& Rajagopal, S. (2017). Fundamental liberties in the Malayan Constitution and the search for a balance, 1956-1957. International Journal of Asia-Pacific Studies, 13(1).

Gafoor, K. A. (2012). Considerations in the measurement of awareness. National Seminar on Emerging Trends in Education. Online Submission

Gaskin, J. (2021). Exploratory factor analysis (EFA). Retrieved from http://statwiki.gaskination.com/index.php?title=EFA\#Discriminant_validity.

George, D., \& Mallery, P. (2003). Cronbach's alpha. SPSS for Windows Step by Step: A Simple Guide and Reference, 11, 231.

Guadagnoli, E., \& Velicer, W. F. (1988) Relation of sample size to the stability of component patterns. Psychological Bulletin, 103(2), pp. 265-275.

Hair, J. F., Black, W. C., Balin, B. J., \& Anderson, R. E. (2010). Multivariate data analysis: Maxwell Macmillan International Editions.

Hair, J. F. Jr., Anderson, R. E., Tatham, R. L., \& Black, W. C. (2006). Multivariate Data Analysis (6th ed.). New Jersey: Prentice-Hall.

Hamid, M. I. A., \& Mohammad, N. A. N. (2018). Legal literacy of educators in Malaysia: An empirical study. International Journal of Business and Society, 19(S2), 187-204.

Hasan, H., Pauzi, S. F. B. M., Mustapha, M., Ghazali, M. S. B., \& Hamid, S. S. S. (2018). Federal Constitution: Determining the level of awareness and knowledge among student leaders of Uitm Cawangan Pahang. Breakthrough Invention, Innovation and Design Exhibition, Series 2018, 57-59. 
Haslbeck, J., \& van Bork, R. (2021). Estimating the number of factors in eExploratory Factor Analysis via out-of-sample Prediction Errors, 1-15

Kai-Ming, J. W. (2020). Remedies for Infringement of Constitutional Rights. Penang Bar, Voix D'Advocat, 1, 24-26.

Kaiser, H. F. (1981). A revised measure of sampling adequacy for factor-analytic data matrices. Educational and Psychological Measurement, 41(2), 379-381.

Khasasi, M. Z. A., Salleh, A. D., \& Zaini, M. (2020). Position of Islam as a Federal religion and a determinant of stable socio-religious relations in Malaysia: Medina charter for reference, Pertanika Journal of Social Science and Humanities, 28(3), 1975-1994

Anuar, M. H., Abdul Wahab, H., Mohamed, M., \& Azhar, A. (2018). Issues in implementing affirmative action in Malaysia. International Journal of Law, Government and Communication, 3(13), 134-139.

Nordin, R., \& Abdullah, A. R. (2017). Human rights, its scope and application: An empirical analysis of future human rights advocates in Malaysia. Pertanika Journals: Social Sciences and Humanities, 25(2), 741-760.

Nudin, N. A., Azmi, A. F., Padil, H. M., Razak, F. A., \& Ahmad, N. L. (2020). 1 Click 2 Liberties Kit: An Analysis on the Effectiveness of Using Kit to Understand Fundamental Liberties. Innovation Insider, Series 1, 49-52.

O'connor, B. P. (2000). SPSS and SAS programs for determining the number of components using parallel analysis and Velicer's MAP test. Behavior research methods, instruments, \& computers, 32(3), 396-402.

Ogunleye, L. I., Oyejola, B. A., \& Obisesan, K. O. (2018). Comparison of some common tests for normality. International Journal of Probability and Statistics, 7(5), 130-137.

Omeje, K. N., Osuagwu, H. O. \& Ugwu, C. F. (2021). E-notice board (ENB) for the faculty community. European Journal of Electrical Engineering and Computer Science, 5(1), 3343.

Padil, H. M., Kasim, E. S., Ismail, N., Zin, N. M., \& Muda, S. (2020). An exploratory factor analysis of financial literacy and awareness of investment scam. International Invention, Innovative and Creative (INIIC) Conference proceedings, Series 2/2020, 61-67

Shrestha, N. (2021). Factor analysis as a tool for survey analysis. American Journal of Applied Mathematics and Statistics, 9(1), 4-11.

Singh, S., \& Singh, H. (2015). Human rights awareness among B. ED. Students. International Journal of Education, 4.

Sormin, E., Julianti, K., Nadeak, B., \& Naibaho, L. (2019). Use of construction inquiri learning model to improve the interest of learning students grade XI SMA Angkasa 2 in coloid materials. PEOPLE International Journal of Social Sciences, 5(2), 908-917.

Spinde, T., Hamborg, F., Kreuter, C., Gipp, B., Gaissmaier, W., \& Giese, H. (2021). How can the perception of media bias in news articles be objectively measured? Best practices and recommendations using user studies. In Proceedings of the ACM/IEEE Joint Conference on Digital Libraries (JCDL).

Tabachnick, B. G., Fidell, L. S. (2001). Using multivariate statistics. Needham Heights: Allyn and Bacon, Boston.

Tehupeiory, A., \& Naibaho, L. (2020). Enhancing community legal awareness of land right disputes through the use of legal aid institutions. International Journal of Psychosocial Rehabilitation, 24(8), 1223-1231. 
Teruel, M. A., Condori-Fernandez, N., Navarro, Elena. \& Gonzales, Pascual. (2018). Assessing the impact of the awareness level on a co-operative game. The Journal of Information and Software Technology, 98, 89-116.

Thurairaj, S., Mogan, S., Abas, A. M., Singh, K. K. S., \& Kumarasamy, J. (2018). The meaning of patriotism among Malaysians: A quantitative study towards reinforcement of national identity and nation state. Jurnal Sultan AlauddinSulaiman Shah, 5(2), 152-170.

Wahab, A. A., \& Khairi, A. (2020). Right to justice and legal aid barriers to the vulnerable noncitizens in Malaysia. Geografia-Malaysian Journal of Society and Space, 16(1), 13-23.

Walsh, K., Rassafiani, M., Mathews, B., Farrell, A., \& Butler, D. (2012). Exploratory factor analysis and psychometric evaluation of the teacher reporting attitude scale for child sexual abuse. Journal of Child Sexual Abuse, 21(5), 489-506.

Yong, A. G., \& Pearce, S. (2013). A beginner's guide to factor analysis: Focusing on exploratory factor analysis. Tutorials in quantitative methods for psychology, 9(2), 79-94. 